\title{
Review: The Geographical Relations of Graham Land
}

Author(s): J. W. G.

Review by: J. W. G.

Source: The Geographical Journal, Vol. 29, No. 6 (Jun., 1907), pp. 668-670

Published by: geographicalj

Stable URL: http://www.jstor.org/stable/1776280

Accessed: 27-06-2016 07:38 UTC

Your use of the JSTOR archive indicates your acceptance of the Terms \& Conditions of Use, available at

http://about.jstor.org/terms

JSTOR is a not-for-profit service that helps scholars, researchers, and students discover, use, and build upon a wide range of content in a trusted digital archive. We use information technology and tools to increase productivity and facilitate new forms of scholarship. For more information about JSTOR, please contact support@jstor.org.

The Royal Geographical Society (with the Institute of British Geographers), Wiley are collaborating with JSTOR to digitize, preserve and extend access to The Geographical Journal 
A few pages are devoted to the aborigines-their characteristics and mode of Jife; their weapons, fishing, corobborees, and burials; their rock carving and paintings, of which drawings are reproduced from Sir George (then Captain). Grey's work, that represent what he saw when he landed on the north-west coast. A number of old drawings of aboriginals hunting, fishing, etc., are also reproduced, as well as old portraits of the early governors.

Some of the notes on the physical features at the beginning of the last chapter must not be taken too seriously.

W. B.

\section{Pacific Islands.}

'Hawaii, Ostmikronesien, und Samoa: Meine Zweite Südseereise (1897-1899) zum Studium der Atolle und jhrer Bewohner.' Von Prof. Dr. Augustin Krämer, Marine-Oberstabsarzt. Mit 20 Tafeln, 86 Abbildungen and 50 Figuren. Stuttgart: Strecker \& Schröder. 1906. Price 10 marks.

The greater part of the time during which Dr. Krämer was engaged in zoological, geological, and more particularly ethnological investigations in the Pacific was spent in Samoa, and his well-known monograph, 'Die SamoaInseln,' appeared in two volumes in 1902. The present volume describes the rest of his travels, to which the name "Südseereise" is scarcely applicable, for they are mainly concerned with Hawaii and the Gilbert and Marshall groups.

The author describes his journey by Chili and Peru, through Guatemala to New Orleans, and from San Francisco to Hawaii. After a few weeks spent at Hawaii and Samoa, a visit was paid to the less frequented Marshall islands, landing at Jaluit (which he notes should be Jalut). Here everything lies packed so closely together on the little patch of coral, that a few hours sufficed to see all the sights of the island. "After three hours as a globe-trotter, I could say that I had seen all that was worth seeing, and quite enough of it; as Forscher I recognized that a rich field of work lay before me." An interesting account of the island follows, as also of some stick-charts (which are figured) of the group. The Gilberts were next visited, and two chapters contain accounts of the islands and inhabitants of the Makin and Peru groups, in which, amongst other matters, we find descriptions of several figures of the tattoo-patterns. After returning to the Marshalls, the author sailed for the little-known island of Nauru (Pleasant island), and records its geographical and ethnographical features. The homeward route was by Sydney, New Caledonia, and Fiji to Samoa.

It would appear from these investigations that the Gilberts show a closer connection with the West Carolines, in spite of the distance between them, than with their near neighbours, the Marshalls, while the latter have distinct affinities with the Eastern Carolines. The author hopes, during his third voyage to the South Seas, in which he is at present engaged, to throw more light on this interesting point.

A. C. HADDON.

\section{POLAR REGIONS.}

\section{The Gejgraphical Relations of Graham Land.}

J. Gunnar Andersson, ' On the Geology of Graham Land.' Bulletin of the Geological Institution of the University of Upsala. Vol. 7, Nos. 13-14, pp. 19-71, pl. i.-vi.

During the voyage of the Jason in 1892-91, Captain Larsen made the first serious contribution to Antarctic palæontology. His collection was small, but very suggestive. Its chief value now, however, is due to the fact that it induced $\mathrm{Dr}$ Otto Nordenskjöld to select Seymour island and its neighbourhood as the field of operations of the Swedish Antarctic Expedition. The work of the expedition was 
interrupted by dramatic adventures, and part of the collections were lost by the wreck of the Antarctic; nevertheless Dr. Nordenskjöld and his colleagues secured results which will make the record of their discoveries one of the primary documents in Antarctic literature.

Reiter's application of Suess's principles to the information about Antarctica available in 1888, led him to predict that Wilkes Land would be found to be of the Atlantic coast type, and Victoria Land and Graham Land of the Pacific type. The additional information collected regarding Victoria Land has left Reiter's conclusion as to the structure of that part of the Antarctic continent still open to doubt; but the work of the Swedish Antarctic Expedition has clearly established his view as to the structure and relations of Graham Land.

The Swedish expedition explored the islands and coasts of eastern Graham Land, which proves to be an area of great geological variety and complexity. The staff was fully competent to investigate its problems, as in addition to Dr. Nordenskjöld, himself a skilled geologist, it included Dr. J. Gunnar Andersson, the present Director of the Geological Survey of Sweden. He has now summarized the geological results of the expedition in a most interesting memoir, which has been written as a preliminary sketch to guide the palæontologists, who are describing the large collections of fossil plants and animals made by the expedition.

The localities studied in detail included part of the South Orkneys, Hope bay at the north eastern end of Graham Land, and the archipelago of Ross island, Seymour island, Snow Hill island, and Lockyer island. The opposite side of Graham Land was investigated by the Belgian expedition, and the author pays a warm tribute of respect to the work of Dr. Arçtowski in that less fruitful geological field. Dr. Nordenskjöld and Dr. Andersson discovered representatives of a long series of fossiliferous rocks ranging from the Jurassic to the Pleistocene; they include Jurassic (apparently Bathonian) plant-beds; the Cretaceous system is represented by the Cenomanian, 'Turonian, and Senonian series, and the Cainozoic by Upper Oligocene or Lower Miocene, Pliocene, and recent shell-beds. In addition to the sedimentary rocks, there are Cainozoic basalts and tuffs, and a large area of plutonic rocks, including gabbros, augite-porphyrite, and quartz diorite; the last rock appears to be the most typical, and Dr. Nordenskjöld describes it as similar to that which he had previously studied along the American coasts of the Pacific, in Alaska, and in the Southern Andes. The age of these plutonic rocks is doubtful; no evidence of their intrusion into the Jurassic was seen; but as no fragments of these rocks could be found in the Jurassic conglomerates, the author is inclined to regard them as due to a Cretaceous intrusion.

The fossils have not yet been fully worked out, but Dr. Andersson tells us enough about them to show their extreme interest, and how instructive a light they throw on the geological history of the Antarctic. The Jurassic plants include species allied to those of Australia and Gondwanaland. The Cretaceous Ammonites, according to a short preliminary note by Prof. Kilian, are similar to those of the Neo-Cretaceous of India; one horizon corresponds to the Cenomanian beds of Ootatoor, and higher horizons represent the Turonian and Senonian. Cainozoic beds, which are referred to the Upper Oligocene or Lower Miocene, remind us that the great middle-Cainozoic marine transgression on to Southern Australia is still undecided between these two dates. The new fossils include a Zeuglodon, five extinct genera of penguins, and some most instructive fossil fish. A Pliocene horizon is probably represented by the Pecten conglomerate of Cockburn island.

The main geographical interest of this memoir is its evidence as to the tectonic structure of the area. Dr. Andersson shows that Graham Land and the adjacent archipelagoes include two divisions. A broken-up volcanic and sedimentary plateau 
lies along the south-eastern coasts of Graham Land ; and an area of folded rocks, including Jurassic sandstones and plutonic masses, forms the axis of Graham Land, the South Shetlands, and the South Orkneys. The folded belt is shown by its composition and geological history to be a geographical continuation of the fold-line of the Andes. The eastward trend of the fold-lines of the Andes, which, as Suess has shown, is one of the most striking features in the mountain system of the southern end of South America, does not, therefore, continue far into the Southern ocean. The line is bent sharply backward round a great gulf to the south of Terra del Fuego, and passes through the South Orkneys, the South Shetlands, and Graham Land on a course to the west, along the southern margin of the Pacific. How far it continues westward, and its relations to the mountains beside the Ross sea, are still uncertain; but the Swedish Antarctic Expedition has established the essential fact of the reflection of the Andean line through Graham Land, and has filled the most important remaining gap in coastal geography by its illuminating discoveries as to the structure and history of the southern coast of the Pacific. The fossil evidence as to the life of the Southern ocean in the latitude of $64^{\circ} \mathrm{S}$., at intervals from Jurassic times to the present, is also an important addition to geological and geographical knowledge.

\section{J. W. G.}

\section{GENERAL.}

\section{Gastaldi and the Cartography of America.}

Stefano Grande, 'Le Carte d'America di Giacomo Gastaldi.' Turin : Carlo Clausen. 1905. With Facsimiles. Price 6 lire.

Prof. Grande, who in a previous work (Journal, vol. 21, p. 561) did useful service in setting forth Gastaldi's general contributions to geographical knowledge, here deals in particular with the maps relating to America, which had not previously been subjected, as a whole, to systematic examination. They are considered in three groups, viz. those which accompanied the Venice Ptolemy of 1548; those prepared to illustrate Ramusio's great collection of voyages ; and a number of maps issued separately. This arrangement is not strictly chronological, but is perhaps justified by the fact that the seven maps dealing in some way or another with America in the 1548 Ptolemy may be regarded as forming the first American atlas. Prof. Grande examines each map in turn, tracing as far as possible its sources, and comparing it with other contemporary maps. In many instances he is able to point to the great improvement introduced by Gastaldi as regards the extension in latitude (and sometimes also in longitude) of the countries delineated. $\mathrm{He}$ is perhaps inclined sometimes to exaggerate the comparative merits of his author. Thus he lays stress on the freedom displayed by Gastaldi from the fantastic notions prevalent regarding the relations of America with Asia, although the idea of a continuous land connection between the two is to be seen in all the general maps. Again, the correct representation of California as a peninsula was not an entire innovation on the part of Gastaldi, e.g. it is to be seen in Sebastian Cabot's planisphere of 1544 . Strange to say, though generally well acquainted with previous writings on sixteenthcentury cartography, the author seems to have no knowledge of the recently discovered Waldseemüller maps, which makes him attribute an original importance which they do not deserve to maps now known to be merely copied from these.

As regards the individual maps, that of South America, in the 1548 Ptolemy, is perhaps one in which Gastaldi's relative correctness is as well shown as in any, in spite of its small size. 'The maps in Ramusio's third volume show generally a greater elaboration than those in the Ptolemy, being based on the information supplied to Ramusio by his ccrrespondence with Fracastoro and others. 'I'hus the map of 'La Nuova Francia,' which embraces the coast of North America from 